\title{
In vitro Removal of Therapeutic Drugs with a Novel Adsorbent System
}

\author{
Karl Reitera,b Valeria Bordonib Giuliano Dall'Olioc Maria Grazia Ricattid \\ Maurizio Solie Salvatore Rupertid Giuliano Soffiatic Elisabetta Galloni ${ }^{\text {b }}$ \\ Vincenzo D'Intini ${ }^{b}$ Rinaldo Bellomo ${ }^{f}$ Claudio Ronco ${ }^{b}$ \\ aUniversity Children's Hospital, Kinderklinik und Kinderpoliklinik am Dr. von Haunerschen Kinderspital, Munich, \\ Germany; Departments of ${ }^{b}$ Nephrology, cClinical Chemistry, dPharmacy, and eImmunohematology, \\ Ospedale San Bortolo, Vicenza, Italy; ${ }^{\mathrm{f}}$ Austin and Repatriation Medical Centre, Heidelberg, Vic., Australia
}

\section{Key Words}

Sorbents · Hemoperfusion - Intoxication - Detoxification • Drugs, intoxication $\cdot$ Middle molecular weight molecules

\begin{abstract}
Background/Aim: Substances in the middle molecular weight range have been shown to play a significant pathogenetic role in as diverse disorders as end-stage renal disease and multiple organ failure. To overcome the limitations in the amount removed by hemofilters, new sorbents with a high biocompatibility are actively being developed. Furthermore, biocompatible sorbents by their nonspecific adsorptive behavior could have great impact on detoxification treatment in exogenous intoxications. We performed an in vitro evaluation of a newly developed highly biocompatible sorbent cartridge (Betasorb ${ }^{\circledR}$ ), examining its adsorptive capacity concerning therapeutic drugs. Methods: Uremic blood spiked with a range of therapeutic drugs was recirculated for $2 \mathrm{~h}$ in an in vitro hemoperfusion circuit containing a Betasorb device for hemoperfusion. The drug concentrations before and after the passage of the cartridge were measured, and the total amount removed was calculated. Results: The sorbent showed effective removal of glyco-
\end{abstract}

\begin{tabular}{ll}
\hline KARGER & (c) 2002 S. Karger AG, Basel \\
Fax +41 61306 1234 & 0253-5068/02/0204-0380\$18.50/0 \\
$\begin{array}{l}\text { E-Mail karger@karger.ch } \\
\text { www.karger.com }\end{array}$ & $\begin{array}{l}\text { Accessible online at: } \\
\text { www.karger.com/journals/bpu }\end{array}$
\end{tabular}

peptide antibiotics, digoxin, theophylline, phenobarbital, phenytoin, carbamazepine, and valproic acid. Moderate removal could be demonstrated for tacrolimus and cyclosporine A; aminoglycosides were removed to a small extent only. Conclusions: Betasorb hemoperfusion shows a potent adsorptive capacity concerning therapeutic drugs (except aminoglycosides) and could be of major value in the treatment of intoxications. On the other hand, drug monitoring and possible adjustments are necessary during Betasorb hemoperfusion to maintain the therapeutic ranges of the drugs in blood.

Copyright @2002 S. Karger AG, Basel

\section{Introduction}

In chronic hemodialysis, much effort is invested in improving the long-term morbidity by removal of toxic substances in the middle molecular weight range (e.g., $\beta$ microglobulin). These molecules accumulate in chronic renal failure and are not sufficiently removed by conventional hemodialyzers, either by using diffusion or convection [1]. Therefore, increasingly sophisticated techniques for blood purification utilizing high convective rates and/ or adsorption mechanisms are being developed to expand

Dr. Claudio Ronco

Department of Nephrology, Ospedale San Bortolo

I-36100 Vicenza (Italy)

Tel. +390444993 869, Fax +390444993949

E-Mail cronco@goldnet.it 
the range of substances removed by renal replacement techniques.

In the intensive care environment renal replacement therapy is a well-established treatment modality for acute renal failure. Renal failure is frequently seen in multiple organ failure syndrome caused by the systemic inflammatory response syndrome. Cytokines acting as protagonists in this syndrome have molecular weights in the middlemolecular weight range. A growing body of evidence suggests a possible beneficial role of removal of middle molecular weight substances in addition to uremic toxins in the septic syndrome [2].

Finally, further refinement of blood purification techniques relying on sorbent devices could conceivably have a major impact on detoxification therapy in exogenous intoxications (including poisons and drugs). Hemoperfusion techniques using charcoal cartridges are used in only very selected cases, mostly because of cost and poor hemocompatibility of the sorbent material, leading to platelet drop and leukopenia [3]. Increasing charcoal biocompatibility by coating leads to a significant loss of adsorbing capacity, rendering charcoal hemoperfusion a modality of limited usefulness. Through the availability of new synthetic polymers with remarkable adsorption capacity in addition to excellent biocompatibility, the role of hemoperfusion in the treatment of intoxications possibly will have to be revised. Nevertheless, since adsorption is not selective with resins and other sorbents, unwanted losses of beneficial substances or active drugs may occur during treatment. In this view, it is essential to define the characteristics of a given sorbent in terms of the adsorption capacity for drugs. This approach will define the possible indications in the case of intoxication and overdose, but also the required prescriptive adjustments in the case of a renal replacement treatment carried out with the sorbent.

We studied a new hemoperfusion cartridge (Betasorb ${ }^{\circledR}$; Renal Tech) which has been designed for high-efficiency removal of substances in the middle molecular weight range like $\beta_{2}$-microglobulin [4] and cytokines [5]. Due to the unpredictable nature of adsorption, we expected this sorbent device to have a high removal capability concerning drugs. Excellent hemocompatibility of the Betasorb cartridge has been shown in earlier studies [6].

The aim of this in vitro-study was to evaluate the adsorption capacity in whole blood for several commonly employed drugs. This serves the purpose of providing pharmacokinetic data as part of the preclinical evaluation as well as delineating a possible role for the cartridge in intoxication treatment.

\section{Materials and Methods}

\section{Experimental Setup}

The investigation was performed within a set of experiments examining the adsorptive capacity of drugs by the Betasorb device applied to uremic blood. Uremic blood was produced in vitro by mixing concentrated ultrafiltrate from a chronic dialysis patient with erythrocyte concentrates donated by healthy volunteers. The experiment was performed twice in an identical fashion, but using ultrafiltrate of 2 different patients.

About 40 liters of ultrafiltrate derived from one hemofiltration session was used. Subsequently, this amount was recirculated in an in vitro circuit utilizing a low-flux polysulfone hemofilter (Fresenius F8, FMC) until about $1,200 \mathrm{ml}$ concentrated fluid was obtained. Assuming a sieving coefficient of 0.5 of the hemofiltration membrane used in the patient and a sieving coefficient of 0.05 of the lowflux hemofilter, the final product was expected to be isotonic to plasma water but containing middle molecules at a concentration similar to that of the uremic plasma at the beginning of a hemodialysis session. We confirmed this in a previous experiment [6]. Then a portion of ultrafiltrate was mixed with two bags of concentrated erythrocytes to obtain a whole amount of reconstituted blood of $1,200 \mathrm{ml}$ with a hematocrit of about $30 \%$. This amount was divided into two aliquots of $600 \mathrm{ml}$ each, to which the drugs to be studied were added immediately before the experiment (fig. 1).

The blood was circulated in an in vitro hemoperfusion circuit for $120 \mathrm{~min}$ at a set flow rate of $250 \mathrm{ml} / \mathrm{min}$ on a hemodialyzer machine. Adequate mixing in the blood reservoir was ensured by careful positioning of arterial and venous lines. Pre- and postcartridge pressures were measured continuously (fig. 2). A 100-gram Betasorb pilot cartridge was used for the experiments.

Blood samples for determination of drug levels were drawn at the sampling ports placed before and after the cartridge at $0,5,15,30$, 60,90 , and $120 \mathrm{~min}$ from the start of the experiment.

Instantaneous removal was measured by the arteriovenous difference multiplied by the flow; cumulative removal was calculated by the reservoir concentration of the specific drug at the beginning and at the end of the experiment corrected by variations in the reservoir volume due to blood samples. Progressive changes in the reservoir concentration were monitored by the concentration in the arterial line at different times of the experiments. Each experiment was performed twice except for tacrolimus.

\section{Laboratory Methods}

The drug levels were determined by the following methods: carbamazepine, phenytoin, phenobarbital, and theophylline by particleenhanced turbidimetric inhibition immunoassay (instrument Dimension RxL; Dade-Behring); digoxin and cyclosporine A by immunoassay (instrument Dimension RxL; Dade-Behring); valproic acid by enzyme-monitored immunoassay (instrument ACA; Dade-Behring); amikacin, gentamicin, netilmicin, teicoplanin, tobramycin, and vancomycin by fluorescence polarization immunoassay (instrument TDx; Abbott), and tacrolimus by microparticle enzyme immunoassay (instrument Imx; Abbott). The formulas used for calculations of the kinetic parameters are given in the appendix. 

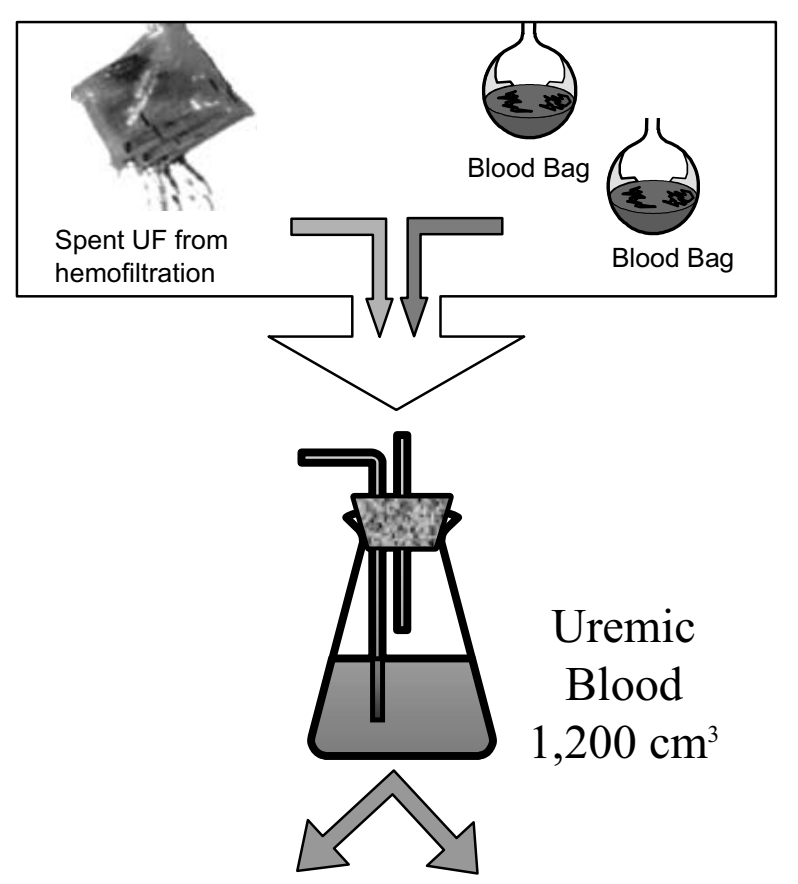

Uremic

Blood

$1,200 \mathrm{~cm}^{3}$

1

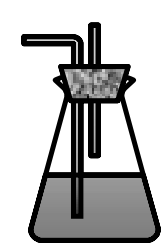

Group 1: Amikacin, Gentamicin, Netilmicin Teicoplanin, Tobramycin, Vancomycin

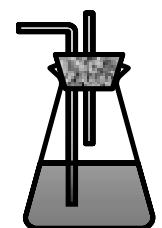

Group 2: Carbamazepine, Digoxin, Phenytoin, Phenobarbital, Theophylline, Valproic Acid, Cyclosporine, Tacrolimus.

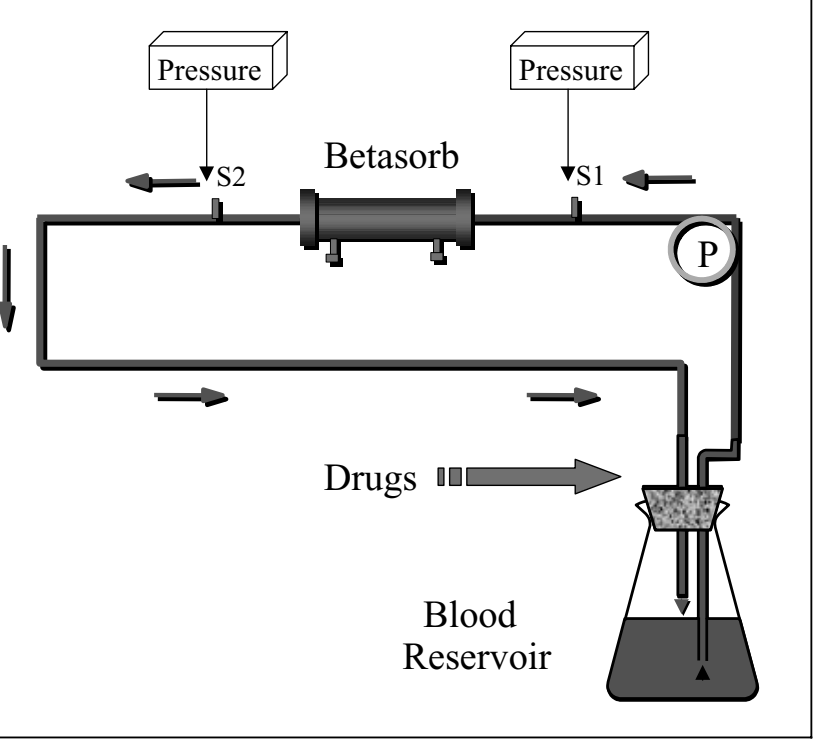

2
Fig. 1. The process of obtaining uremic blood starts from concentrated ultrafiltrate obtained from patients undergoing hemofiltration and normal red cells. The mixture simulates the composition of uremic blood. The batch is then split into two aliquots that are injected with the drugs studied.

Fig. 2. Schematic representation of the in vitro circuit utilized for the study. $\mathrm{P}=\mathrm{Pump} ; \mathrm{S} 1$ and $\mathrm{S} 2$ = sampling ports. 
Table 1. Time course of plasma levels according to sampling site

\begin{tabular}{|c|c|c|c|c|c|c|c|c|c|c|c|c|c|c|c|c|}
\hline \multirow{3}{*}{$\begin{array}{l}\text { Time } \\
\text { min }\end{array}$} & \multicolumn{4}{|c|}{ Amikacin $\mu \mathrm{g} / \mathrm{ml}$} & \multicolumn{4}{|c|}{ Gentamicin $\mu \mathrm{g} / \mathrm{ml}$} & \multicolumn{4}{|c|}{ Tobramycin $\mu \mathrm{g} / \mathrm{ml}$} & \multicolumn{4}{|c|}{ Netilmicin $\mu \mathrm{g} / \mathrm{ml}$} \\
\hline & \multirow{2}{*}{\multicolumn{2}{|c|}{$\begin{array}{l}\text { experiment I } \\
\text { arterial venous } \\
\text { site site }\end{array}$}} & \multirow{2}{*}{\multicolumn{2}{|c|}{$\begin{array}{l}\frac{\text { experiment II }}{\text { arterial venous }} \\
\text { site site }\end{array}$}} & \multirow{2}{*}{\multicolumn{2}{|c|}{$\begin{array}{l}\text { experiment I } \\
\text { arterial venous } \\
\text { site site }\end{array}$}} & \multirow{2}{*}{\multicolumn{2}{|c|}{$\begin{array}{l}\text { experiment II } \\
\text { arterial venous } \\
\text { site site }\end{array}$}} & \multirow{2}{*}{\multicolumn{2}{|c|}{$\begin{array}{l}\text { experiment I } \\
\text { arterial venous } \\
\text { site site }\end{array}$}} & \multirow{2}{*}{\multicolumn{2}{|c|}{$\begin{array}{l}\text { experiment II } \\
\text { arterial venous } \\
\text { site site }\end{array}$}} & \multirow{2}{*}{\multicolumn{2}{|c|}{$\begin{array}{l}\text { experiment I } \\
\text { arterial venous } \\
\text { site site }\end{array}$}} & \multirow{2}{*}{\multicolumn{2}{|c|}{$\begin{array}{l}\text { experiment II } \\
\text { arterial venous } \\
\text { site site }\end{array}$}} \\
\hline & & & & & & & & & & & & & & & & \\
\hline \multicolumn{17}{|l|}{ a } \\
\hline 0 & \multicolumn{2}{|c|}{520} & \multicolumn{2}{|l|}{97} & \multicolumn{2}{|c|}{153} & \multicolumn{2}{|c|}{26.2} & \multicolumn{2}{|c|}{135} & \multicolumn{2}{|c|}{21.6} & \multicolumn{2}{|c|}{180} & \multicolumn{2}{|r|}{24.3} \\
\hline 15 & 493 & 472 & 85 & 83 & 138 & 127 & 19.1 & 18.7 & 125 & 117 & 16.7 & 16.4 & 149 & 138 & 15. & $\begin{array}{ll}6 & 15.3\end{array}$ \\
\hline 30 & 497 & 478 & 84 & 85 & 138 & 121 & 18.6 & 18.4 & 117 & 108 & 16.9 & 16.5 & 146 & 144 & 15.2 & 15.5 \\
\hline 60 & 493 & 472 & 84 & 85 & 136 & 132 & 17.6 & 17.6 & 113 & 113 & 17.6 & 17.1 & 146 & 142 & 14. & $7 \quad 15$ \\
\hline 120 & 496 & 473 & 83 & 84 & 129 & 128 & 17.0 & 16.8 & 111 & 119 & 17.4 & 17.8 & 147 & 149 & 13. & 14 \\
\hline \multirow{3}{*}{$\begin{array}{l}\text { Time } \\
\text { min }\end{array}$} & & ancomyci & $\operatorname{cin} \mu \mathrm{g} / \mathrm{ml}$ & & & & Teicoplan & $\operatorname{in} \mu \mathrm{g} / \mathrm{ml}$ & & & & Digoxin 1 & $\mathrm{ng} / \mathrm{ml}$ & & & \\
\hline & & cperiment & & experim & ment II & & experimen & & experi & riment II & & experime & ent I & & perimen & at II \\
\hline & & terial & $\begin{array}{l}\text { venous } \\
\text { site }\end{array}$ & $\begin{array}{l}\text { arterial } \\
\text { site }\end{array}$ & $\begin{array}{l}\text { venou } \\
\text { site }\end{array}$ & & $\begin{array}{l}\text { arterial } \\
\text { site }\end{array}$ & $\begin{array}{l}\text { venous } \\
\text { site }\end{array}$ & $\begin{array}{l}\text { arteric } \\
\text { site }\end{array}$ & $\begin{array}{ll}\text { ial ven } & \text { ven } \\
& \text { site }\end{array}$ & & $\begin{array}{l}\text { arterial } \\
\text { site }\end{array}$ & $\begin{array}{l}\text { venous } \\
\text { site }\end{array}$ & & terial & $\begin{array}{l}\text { venous } \\
\text { site }\end{array}$ \\
\hline b & & & & & & & & & & & & & & & & \\
\hline 0 & & 1,048 & & 221 & & & 179 & & & 65 & & 3,90 & & 6,8 & & \\
\hline 15 & $4^{\prime}$ & 74 & 414 & 42.7 & 35.8 & & 78 & 66 & 25 & 6.5 & & 358 & 86 & 2. & & 1.4 \\
\hline 30 & 3 & 50 & 314 & 15.8 & 8.9 & & 59 & 55 & 2.6 & 0.7 & & 90 & 52 & 0.8 & & 0.5 \\
\hline 60 & 2 & 18 & 205 & $<0.01$ & $<0.01$ & & 36 & 29 & $<0.01$ & $1<0.0$ & & 29 & 22 & 0.2 & & 0.1 \\
\hline 120 & 13 & 37 & 148 & $<0.01$ & $<0.01$ & & 19 & 21 & $<0.01$ & $1<0.0$ & & 16 & 13 & $<0$. & & 0.05 \\
\hline Time & & Cyclospo & orine $\mathrm{ng} / \mathrm{ml}$ & & & & & Theophy & lline $\mu \mathrm{g} / \mathrm{ml}$ & & & & & Tacroli & imus ng/ & \\
\hline & & experime & ent I & & experimer & nt II & & experime & ent I & & experim & nent II & & experin & ment I & \\
\hline & & $\begin{array}{l}\text { arterial } \\
\text { site }\end{array}$ & $\begin{array}{l}\text { venous } \\
\text { site }\end{array}$ & & $\begin{array}{l}\text { arterial } \\
\text { site }\end{array}$ & $\begin{array}{l}\text { venou } \\
\text { site }\end{array}$ & & $\begin{array}{l}\text { arterial } \\
\text { site }\end{array}$ & $\begin{array}{l}\text { venous } \\
\text { site }\end{array}$ & & $\begin{array}{l}\text { arterial } \\
\text { site }\end{array}$ & $\begin{array}{l}\text { veno } \\
\text { site }\end{array}$ & & $\begin{array}{l}\text { arterial } \\
\text { site }\end{array}$ & & $\begin{array}{l}\text { enous } \\
\text { ite }\end{array}$ \\
\hline C & & & & & & & & & & & & & & & & \\
\hline 0 & & 396 & & & 604 & & & 32.4 & & & 34.4 & & & 84. & & \\
\hline 15 & & 338 & 312 & & 380 & 386 & & 10.2 & 9.0 & & 12.0 & 10.6 & & 21.5 & 2 & 1 \\
\hline 30 & & 310 & 277 & & 347 & 340 & & 9.8 & 9.6 & & 9.7 & 9.6 & & 21.4 & & 9.5 \\
\hline 60 & & 318 & 291 & & 369 & 362 & & 9.7 & 9.5 & & 8.5 & 8.2 & & 20.8 & 2 & 0 \\
\hline 120 & & 233 & 217 & & 306 & 315 & & 9.4 & 9.2 & & 8.9 & 8.6 & & 18.6 & & 1.1 \\
\hline Time & Valprc & oic acid $\mu$ & $\mathrm{ag} / \mathrm{ml}$ & & Phenob & oarbital $\mu \mathrm{g}$ & $\mathrm{g} / \mathrm{ml}$ & & Carbam & nazepine & $\mu \mathrm{g} / \mathrm{ml}$ & & Phenytc & toin $\mu \mathrm{g} / \mathrm{ml}$ & & \\
\hline min & experi & ment I & experim & nent II & experin & nent I & experi & iment II & experim & nent I & experin & iment II & experim & ment I & expe & eriment II \\
\hline & $\begin{array}{l}\text { arteria } \\
\text { site }\end{array}$ & $\begin{array}{l}\text { l venous } \\
\text { site }\end{array}$ & $\begin{array}{l}\text { arterial } \\
\text { site }\end{array}$ & $\begin{array}{l}\text { venous } \\
\text { site }\end{array}$ & $\begin{array}{l}\text { arterial } \\
\text { site }\end{array}$ & $\begin{array}{l}\text { venous } \\
\text { site }\end{array}$ & $\begin{array}{l}\text { arteria } \\
\text { site }\end{array}$ & $\begin{array}{l}\text { l venous } \\
\text { site }\end{array}$ & $\begin{array}{l}\text { arterial } \\
\text { site }\end{array}$ & $\begin{array}{l}\text { venous } \\
\text { site }\end{array}$ & $\begin{array}{l}\text { arterial } \\
\text { site }\end{array}$ & $\begin{array}{l}\text { al venous } \\
\text { site }\end{array}$ & $\begin{array}{l}\text { arterial } \\
\text { site }\end{array}$ & $\begin{array}{l}1 \text { venous } \\
\text { site }\end{array}$ & $\begin{array}{l}\text { arter } \\
\text { site }\end{array}$ & $\begin{array}{l}\text { rial venous } \\
\text { site }\end{array}$ \\
\hline d & & & & & & & & & & & & & & & & \\
\hline 0 & & 05.7 & 123 & 3.7 & 27. & & 61 & 1.4 & 9.6 & & & 2.3 & 16. & 5.3 & & 23.3 \\
\hline 15 & 33.1 & 24.4 & 45.3 & 38.7 & 2.5 & 1.3 & 9.9 & 7.7 & 0.5 & $<0.5$ & 1.4 & 0.6 & 1.8 & 1 & 3.5 & 2.4 \\
\hline 30 & 25.2 & 23 & 36.9 & 34 & 1.3 & 0.8 & 4.4 & 4.1 & $<0.5$ & $<0.5$ & 0.8 & 0.6 & 0.9 & 0.9 & 1.7 & 1.2 \\
\hline 60 & 21.2 & 28.4 & 28.6 & 29.8 & 1.2 & 0.6 & 4 & 3.4 & $<0.5$ & $<0.5$ & $<0.5<$ & $<0.5$ & $<0.5<$ & $<0.5$ & $<0.5$ & $<0.5$ \\
\hline 120 & 20.6 & 17.3 & 26.7 & 27.6 & 0.5 & 0.5 & 2.3 & 2 & $<0.5$ & $<0.5$ & $<0.5<$ & $<0.5$ & $<0.5<$ & $<0.5$ & $<0.5$ & $<0.5$ \\
\hline
\end{tabular}

\section{Results}

All experiments were performed without major interruptions or technical problems. In detail, the end-to-end pressure drop in the cartridge remained stable over time, indicating a constant patency of the unit and the absence of major changes in the priming volume of the sorbent cartridge (fig. 3). The data are reported in table 1. The respective drug concentrations are listed with regard to the relative time points of sampling and sampling site (ar- 
terial or venous, i.e., before or after the hemoperfusion cartridge). During the experiment, the blood $\mathrm{pH}$ value remained stable at 6.8 . The cartridge performed very well with respect to hemocompatibility (table 2), showing no changes in platelet and leukocyte counts. As depicted in

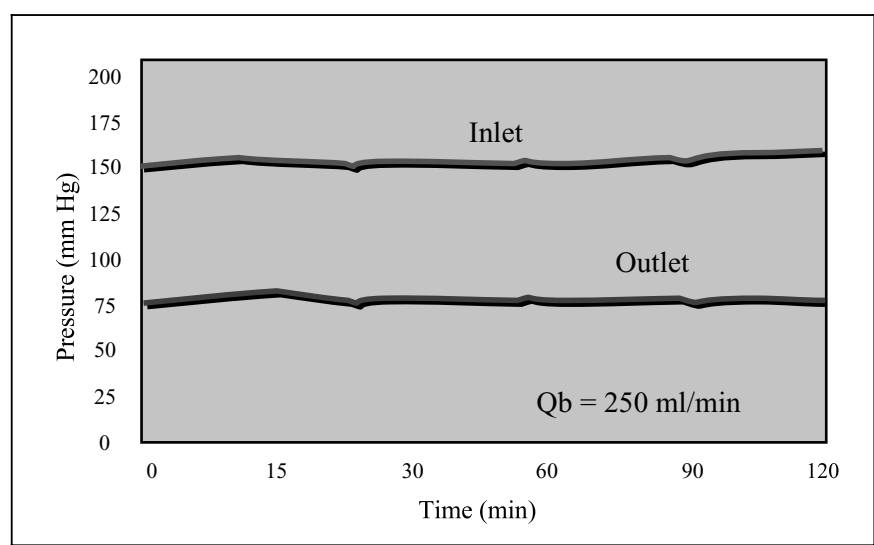

Fig. 3. Pressure behaviours at the inlet and outlet of the cartridge during the study. The constant value indicates that no clotting or loss of surface area occurred during the study. figures 4 and 5, there were no visible signs of blood stasis during and at the end of the hemoperfusion session as well as after rinsing the cartridge with saline.

Aminoglycosides were removed to a marginal degree. Figure 6 shows the percentages by which the plasma levels declined over time, the arterial value at time point zero being set at $100 \%$. The plasma levels of amikacin decreased by 4.6 and $14.4 \%$. Practically all removal took place within the first $15 \mathrm{~min}$. Over the following $90 \mathrm{~min}$, adsorption and desorption from the membrane seemed to be in equilibrium, as a reduction in plasma levels by passage over the cartridge still was measurable at specific time points, but not overall.

Netilmicin, tobramycin, and gentamicin (fig. 6, 7) showed a similar behavior, with maximal removal also within the first $15 \mathrm{~min}$. With lower initial plasma drug levels, the relative amount of removal was higher (up to $42 \%$ with netilmicin). Therefore, the relative removal rates generally were larger in the second set of experiments, where the initial drug concentrations were lower because of comparable absolute amounts of removal.

Vancomycin, teicoplanin, digoxin, carbamazepine, phenytoin, and phenobarbital were practically completely

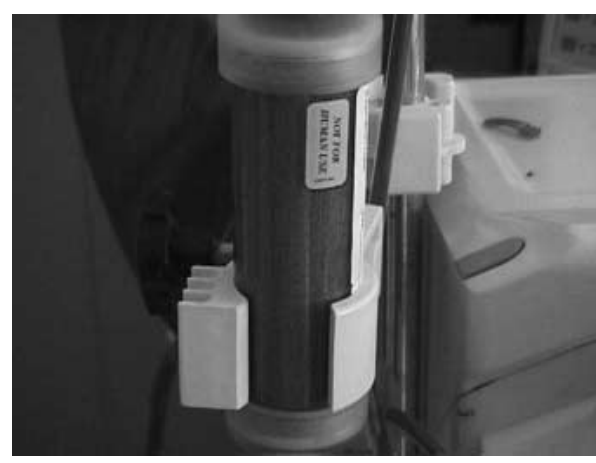

5 min after start

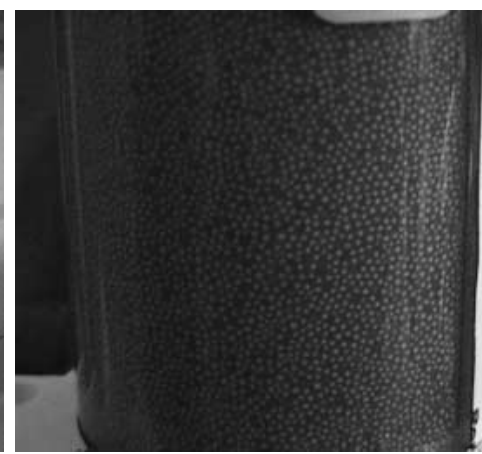

60 min after start
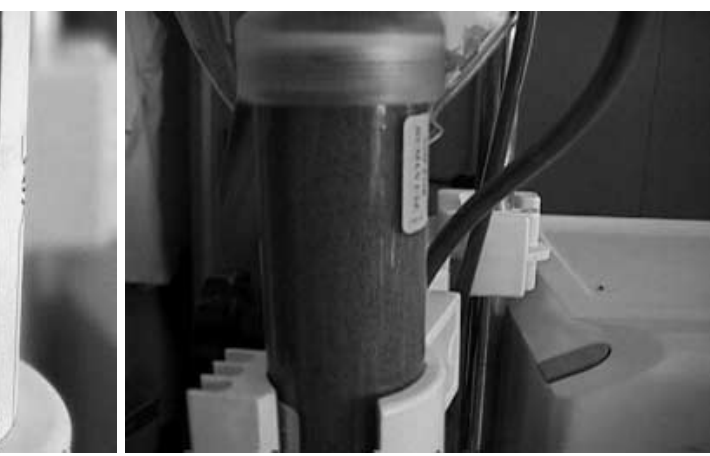

90 min after start

Fig. 4. Pictures of the cartridge at different times during the study. It is evident that a homogeneous distribution of blood is present for the entire duration of the experiment.

Table 2. Hemocompatibility: standard blood values at start and end of the experiments

\begin{tabular}{|c|c|c|c|c|c|c|c|c|c|c|}
\hline \multirow{2}{*}{$\begin{array}{l}\text { Time } \\
\text { min }\end{array}$} & \multicolumn{2}{|c|}{$\mathrm{RBC} 10^{6} / \mathrm{mm}^{3}$} & \multicolumn{2}{|c|}{ Hct, $\%$} & \multicolumn{2}{|c|}{$\mathrm{WBC} 10^{3} / \mathrm{mm}^{3}$} & \multicolumn{2}{|c|}{ Platelets G/1 } & \multicolumn{2}{|c|}{ Albumin, $\mathrm{g} / \mathrm{l}$} \\
\hline & $\operatorname{exp~I~}$ & $\exp I I$ & $\exp I$ & $\exp$ II & $\operatorname{exp~I~}$ & $\exp I I$ & $\operatorname{exp~I}$ & $\exp I I$ & $\operatorname{exp~I}$ & $\exp$ II \\
\hline 0 & 2.74 & 3.56 & 25.9 & 32.3 & 1.22 & 1.02 & 34 & 7 & 0.4 & 0.8 \\
\hline 120 & 2.71 & 3.27 & 25.7 & 29.6 & 1.04 & 0.51 & 24 & 1 & 0.2 & 0.5 \\
\hline
\end{tabular}




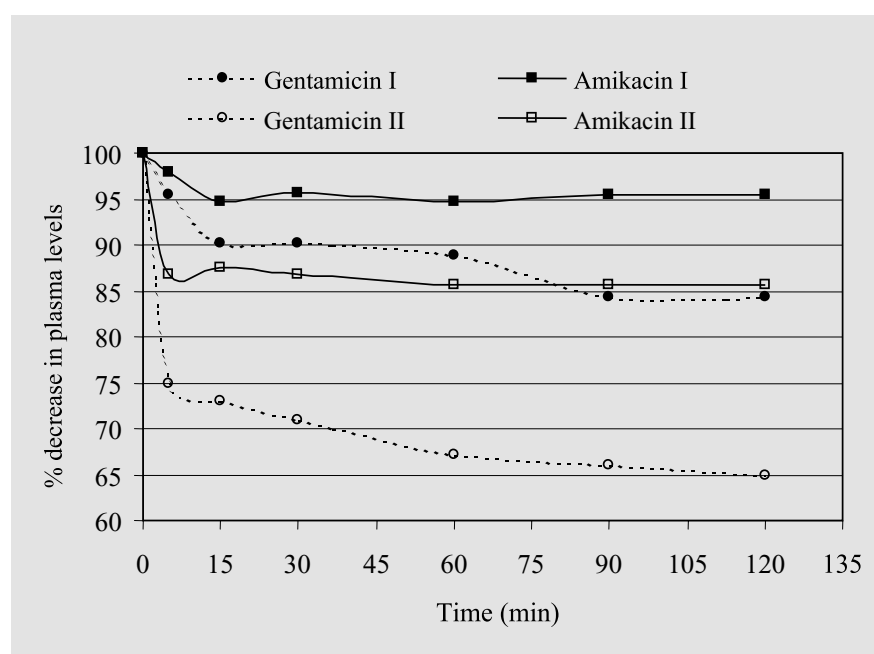

Fig. 6. Percent decrease in blood concentration of gentamicin and amikacin over time.

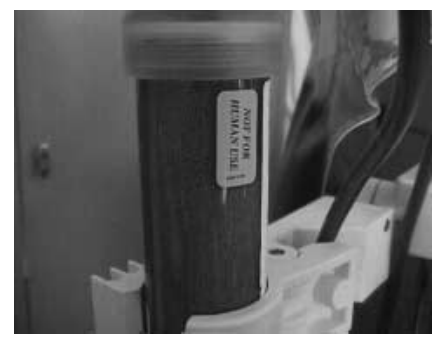

Cartr. 105 at the end

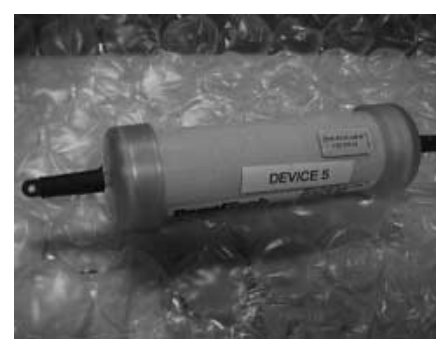

Cartr. 105 after Rinse

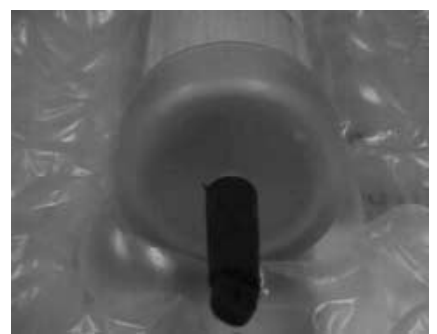

Arterial Port after Rinse

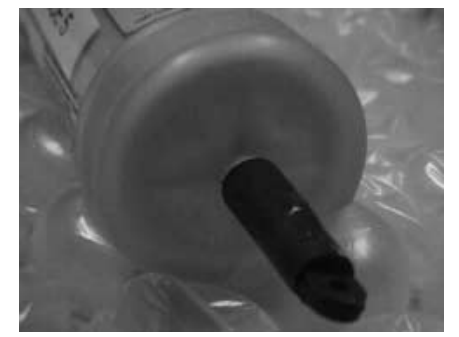

Venous port after Rinse

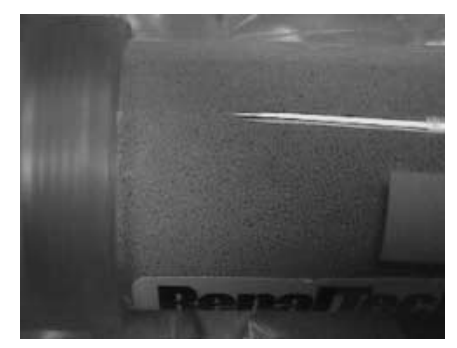

Detailed image after Rinse

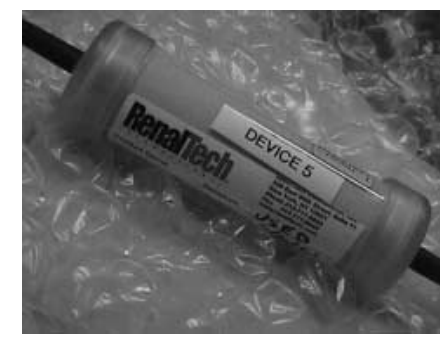

Cartr. 105 after Rinse
Fig. 5. Pictures of the cartridge after the experiment. The sorbent appears clean and well rinsed confirming the absence of blood residuals.

Removal of Drugs with a Novel Adsorbent System

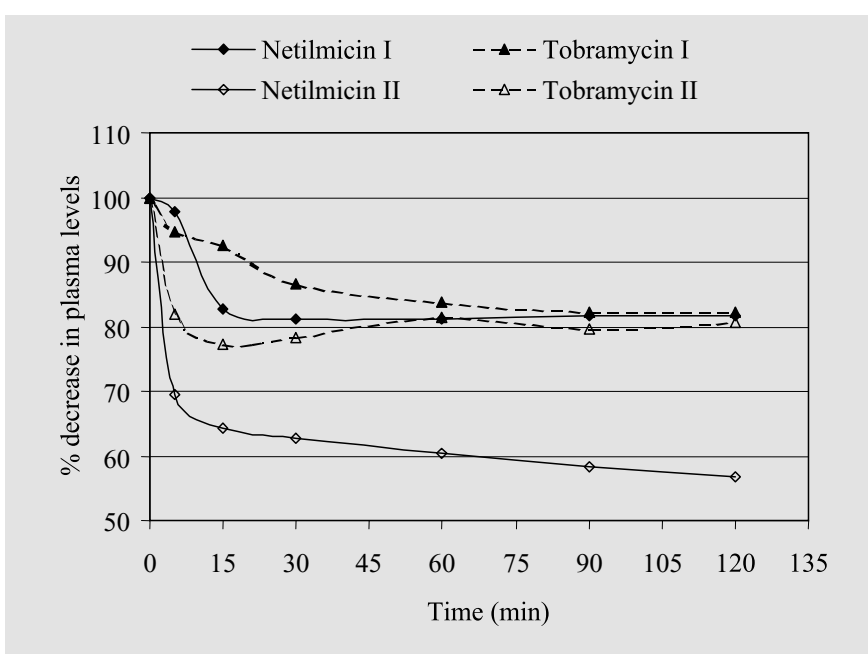

Fig. 7. Percent decrease in blood concentration of netilmycin and tobramycin over time.

removed, predominantly within $5-15$ min (fig. 8, 9). Slight but insignificant amounts of desorption were apparent only with vancomycin between time points 60 and $120 \mathrm{~min}$ (the values after the filter passage being slightly higher than those before). Theophylline, tacrolimus (fig. 10), and valproic acid (fig. 9) were significantly adsorbed to an extent of $72-84 \%$. Tacrolimus and valproic acid showed minimal desorption after $60 \mathrm{~min}$. Cyclosporine (fig. 10) showed intermediate removal amounts of 45 and $48 \%$. In the first experiment, there was ongoing adsorption of cyclosporine over $120 \mathrm{~min}$, whereas in the second set a slight desorption could be demonstrated after $60 \mathrm{~min}$. The cumulative removal for all drugs examined is shown in table 3.

\section{Discussion}

Chronic hemodialysis patients continue to have a significant morbidity despite considerable improvement in filter and dialysis techniques with high-efficiency removal of low molecular weight uremic toxins [1]. Over the last years more and more (definitive and probable) uremic toxins in the middle molecular weight range have been identified. A search for means to effectively remove these toxins has been launched. As sorbent materials with a much higher biocompatibility as compared with charcoal have become available, a renewed interest in blood purification modalities using sorbents has developed [6]. Apart from employment in chronic hemodialysis, a further ex- 


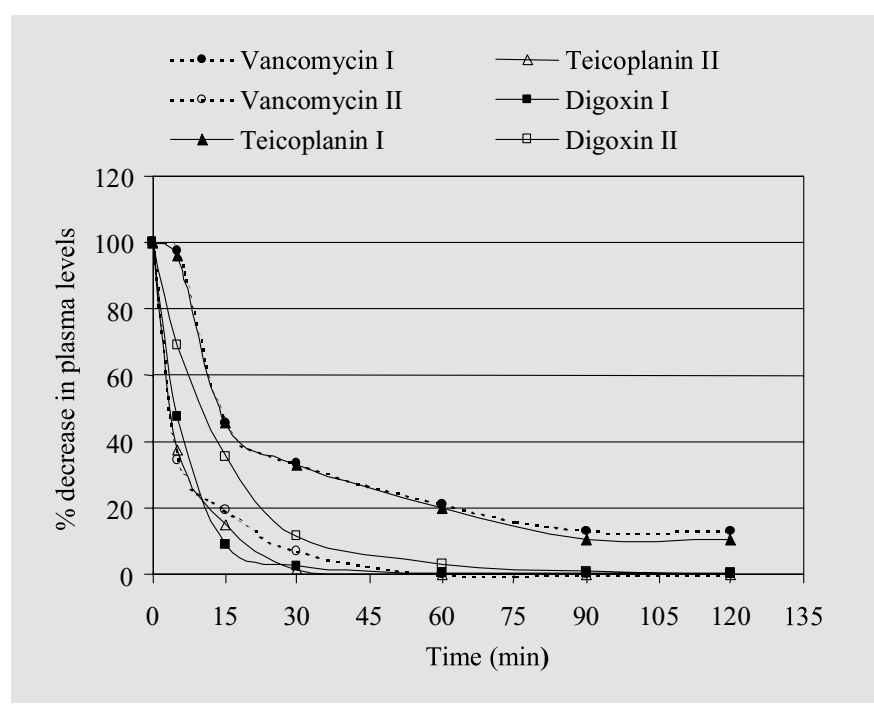

Fig. 8. Percent decrease in blood concentration of vancomycin, teicoplanin and digoxin over time.

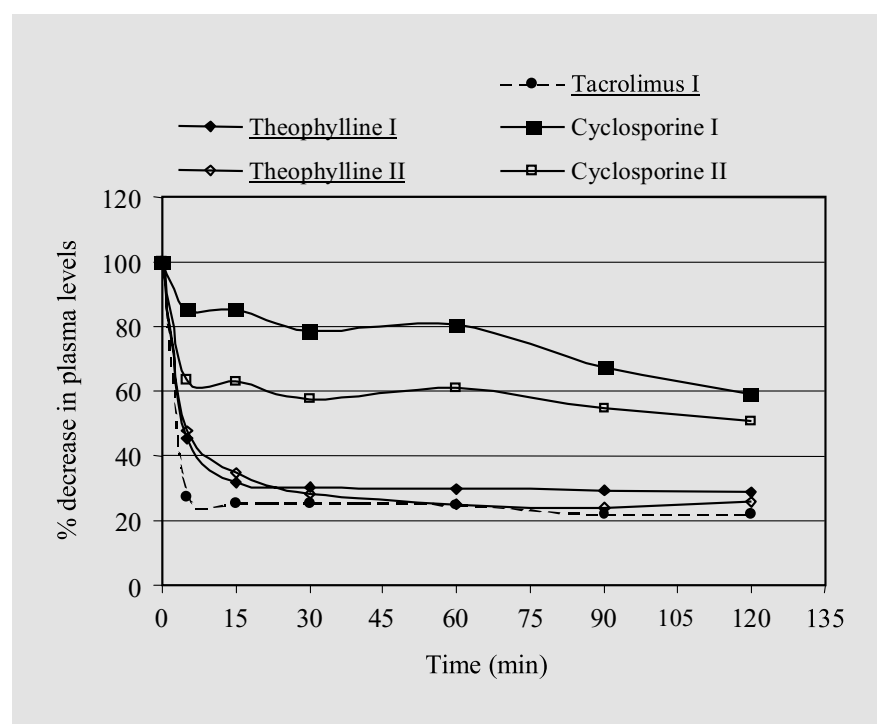

Fig. 10. Percent decrease in blood concentration of theophylline, tacrolimus and cyclosporine over time.

citing indication for sorbent hemoperfusion undergoing active investigation is in patients with systemic inflammatory response syndrome for mediator removal, e.g., cytokines [2]. Furthermore, a number of currently used drugs may sometimes be observed at toxic concentrations (e.g., theophylline, digoxin, and valproic acid) due to accidental overdose or to other conditions. These are major

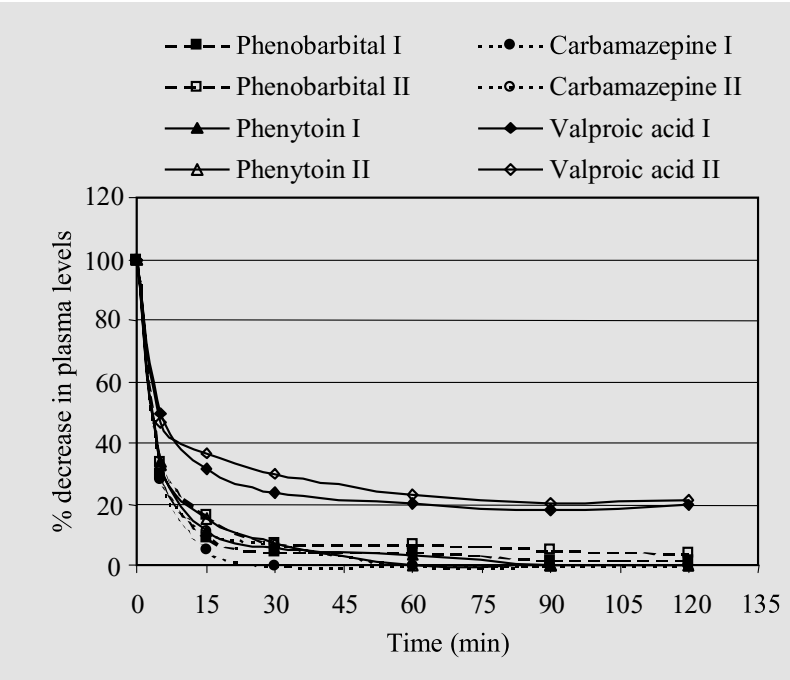

Fig. 9. Percent decrease in blood concentration of phenobarbital, phenytoin, carbamazepine and vaproic acid over time.

challenges for detoxification therapies, as protein binding and/or hydrophobicity of the molecules often preclude effective removal by forced diuresis or hemofiltration/ dialysis modalities. In severe intoxications charcoal hemoperfusion has been a historical standard treatment. However, its application has been limited by low biocompatibility (when uncoated) or less-than-optimal adsorptive capacity (when made more biocompatible by coating). Adsorbents of any type - excluding antibody-coated membranes for immune system specific removal - characteristically behave nonspecifically in their adsorptive process. Therefore, studies are important to evaluate the impact of their use on the plasma levels of therapeutic drugs either for detoxification purposes or for optimization of drug prescription.

In this study, we evaluated the performance of the hemoperfusion cartridge Betasorb. This device is a specifically developed adsorption column for removal of $\beta_{2-}$ microglobulin $(11.8 \mathrm{kD})$. It contains hydrated, hypercross-linked polystyrene resin beads (designed to remove molecules between 4 and $20 \mathrm{kD}$; bead size $400-1,000 \mu \mathrm{m}$ ) with an enhanced proportion of mesopores in the range of 2-20 nm. The cartridge shows an excellent hemocompatibility $[6,7]$ through coating by hydrophilic substitution of vinyl chains [8]. The flow-dynamic pattern has been characterized in vitro [9]. With ex vivo-testing in whole blood, the plasma levels of $\beta_{2}$-microglobulin, tumor necrosis factor alpha, and interleukin 1 beta could be significantly reduced $[5,7]$. In dogs with chronic renal failure, the plas- 
Table 3. Total mass removal over $120 \mathrm{~min}$

\begin{tabular}{lcc}
\hline & \multicolumn{2}{c}{ Total amount } \\
\cline { 2 - 3 } & at start & removed \\
\hline Amikacin, mg & 624 & 128 \\
Gentamicin, mg & 183.6 & 54.6 \\
Tobramycin, mg & 162 & 51 \\
Netilmicin, mg & 216 & 69 \\
Vancomycin, mg & 1,258 & 1,121 \\
Teicoplanin, mg & 198 & 198 \\
Digoxin, $\mu \mathrm{g}$ & 4,680 & 4,664 \\
Cyclosporine, $\mu \mathrm{g}$ & 725 & 434 \\
Theophylline, mg & 412.8 & 32.8 \\
Tacrolimus, $\mu \mathrm{g}$ & 101.2 & 83.5 \\
Valproic acid, mg & 148 & 123 \\
Phenobarbital, mg & 73.6 & 71.5 \\
Carbamazepine, mg & 14.8 & 14.8 \\
Phenytoin, mg & 28 & 28 \\
\hline
\end{tabular}

ma $\beta_{2}$-microglobulin levels were reduced in excess of $70 \%$ per session of combined hemodialysis and Betasorb hemoperfusion [4]. First clinical experience demonstrated a decrease in the plasma concentrations of $\beta_{2}$-microglobulin by 79 and $69 \%[10,11]$.

We now have characterized the adsorptive performance of this device with regard to 14 commonly used drugs. The drugs examined differ in molecular weight (range 236-1,993 Da), protein binding (range 0-95\%), as well as solubility (very water soluble to insoluble). As the blood preparation examined contained a high number of drugs, possible chemical interactions could be of concern. To our knowledge, no such interactions in whole blood have been described for the drugs we used in our experiments.

The different drugs studied encompass a wide range of medications commonly prescribed in internal medicine and the intensive care setting. They are potent drugs; consequently, their plasma levels often need to be kept in a narrow therapeutic range. Therefore, it is vital to know to what extent plasma levels are influenced by hemoperfusion. On the one hand, hemoperfusion performed for a reason not related to drug intoxication could lead to dangerous lowering of the plasma levels of the drug. On the other hand, obviously a high absorptive capacity for toxic drugs would open a wide avenue for therapeutic use in detoxification.

All aminoglycosides tested in our study were poorly adsorbed. The use of the Betasorb device probably should be of no significance concerning their dosage. The other drugs studied were removed to a significant degree. Hence, additional dosages may be necessary to be given and strict serum drug level monitoring performed when using the Betasorb device.

Concerning intoxications with digoxin, carbamazepine, teicoplanin, vancomycin, valproic acid, phenytoin, phenobarbital, and theophylline, Betasorb hemoperfusion demonstrates a potentially important role in detoxification. Important to note is the possibility of later desorption of the drug from the membrane. It would seem prudent to limit hemoperfusion in drug intoxication to a period of $1 \mathrm{~h}$ or to increase the size of the cartridge employed for this purpose. In interpreting these results, it should be kept in mind that only a prototype device containing $100 \mathrm{~g}$ sorbent was used. For clinical implementation, the amount of sorbent per cartridge will certainly be increased by the manufacturer.

Desorption from the membrane after establishment of a concentration, equilibrium with plasma is a known process which depends on the physicochemical characteristics of the adsorption. Potentially relevant desorption should be detectable by a pre-post cartridge gradient with a higher drug concentration after passage of the filter. This was the case, to a minimal extent, for valproic acid, teicoplanin, vancomycin, netilmicin, and tobramycin without clinically significant impact on the plasma levels. Nevertheless, with very high plasma drug levels as encountered in intoxications, desorption should be a function of absolute adsorbing capacity of the cartridge. The possibility that desorption then takes place at higher plasma levels cannot be excluded by our data.

Tacrolimus is known to accumulate in erythrocytes, and equilibrium dynamics over the erythrocyte membrane have to be considered. The same is valid for cyclosporine. In our study, both drugs showed the lowest removal rates by Betasorb as compared with other drugs. Slow transport across the erythrocyte membrane may be the cause. On the other hand, we could demonstrate a slight desorption starting after $60 \mathrm{~min}$ of perfusion which argues for saturation of the cartridge with only moderately strong affinity as the underlying mechanism. For clarifying this issue, further investigations including a prolonged perfusion time have to be conducted.

Our results compare favorably with sorbent devices in use up to now, like charcoal [3] and Amberlite resins [13]. Notably, the Betasorb cartridge, as compared with older sorbents, has a superior biocompatibility [14]. Of the more recently developed sorbent devices [reviewed in 15], only the microsphere detoxification system has undergone in vitro testing with respect to drugs. Only data on 
phenobarbital removal are available, showing significant effects [16].

In conclusion, in this study, we investigated in an in vitro hemoperfusion circuit the drug-adsorbing capacity of the new synthetic sorbent device Betasorb. The removal kinetics are also described. Excluding aminoglycosides, we could demonstrate an impressive removal of a number of therapeutic drugs relevant in current medical and intensive care practice. The data are relevant for drug dosing during hemoperfusion. Modern sorbent technology due to its excellent biocompatibility and high adsorbent capacity has the potential to become the first-line treatment modality in a number of severe intoxications by medical drugs.

\section{Appendix}
Arterial venous difference $(\Delta)$
Removal rate
Conc $_{\text {art }}-$ Conc $_{\text {ven }}$
$\left(\right.$ Conc $_{\text {art }}-$ Conc $\left._{\text {ven }}\right) \times \mathrm{Qb}$
Cumulative mass removal (at t $)\left(\text { Conc }_{\text {res }} \times \mathrm{V}\right)_{\text {base }}-\left(\text { Conc }_{\text {res }} \times \mathrm{V}\right)_{\mathrm{t}}$
Clearance
$\left[\left(\right.\right.$ Conc $_{\text {art }}-$ Conc $\left._{\text {ven }}\right) /$ Conc $\left._{\text {art }}\right] \times \mathrm{Qb}$

where Conc $_{\text {art }}=$ concentration of the solute before the cartridge, Conc $_{\mathrm{ven}}=$ concentration of the solute after the cartridge, Conc $\mathrm{res}_{\mathrm{re}}=$ concentration of the solute in the reservoir, $\mathrm{V}=$ volume of blood in the reservoir, $\mathrm{Qb}=$ effective blood flow.

\section{References}

1 Leypoldt JK, Cheung AK, Carroll CE, Stannard DC, Pereira BJ, Agoda LY, Port FK: Effect of dialysis membranes and middle molecule removal on chronic hemodialysis patient survival. Am J Kidney Dis 1999;33:349-355.

2 Ronco C, Brendolan A, Dan M, Piccinni P, Bellomo R, Wratten ML, Inguaggiato P, Tetta $\mathrm{C}$ : Use of sorbents in acute renal failure and sepsis; in Ronco C, Winchester JF (eds): Dialysis, Dialyzers and Sorbents. Contrib Nephrol. Basel, Karger, 2001, vol 133, pp 180-193.

3 Winchester JF: Use of dialysis and hemoperfusion in treatment of poisoning; in Daugirdas JT, Ing TS (eds): Handbook of Dialysis, ed 2. Boston, Little, Brown, 1994.

4 Brady JA: Beta-2-microglobulin removal in the uremic canine with combined hemodialysis/ hemoperfusion using a new adsorbent device (abstract). J Am Soc Nephrol 2000;11:2954.

5 Brady JA: Ex vivo cytokine clearance with a new adsorbent material from endotoxin-stimulated whole blood (abstract). J Am Soc Nephrol 2000;11:3092.

6 Bosch T, Wendler T, Duhr C, Brady J, Samtleben W: Ex-vivo biocompatibility of a new beta-2-microglobulin adsorbent during hemoperfusion with human whole blood (abstract). $\mathrm{J}$ Am Soc Nephrol 2000;11:257.
7 La Greca G, Brendolan A, Ghezzi PM, De Smet R, Tetta C, Gervasio R, Ronco C: The concept of sorbent in hemodialysis. Int J Artif Organs 1998;21:303-308.

8 Brady JA: Ex vivo performance of a new beta2-microglobulin adsorbent material (abstract). J Am Soc Nephrol 2000;11:2953.

9 Davankov V, Pavlova L, Tsyurupa M, Brady J, Balsamo M, Yousha E: Polymeric adsorbent for removing toxic proteins from blood of patients with kidney failure. J Chromatogr B 2000;739:73-80.

10 Polaschegg HD, Ronco C, Soli M: Characterization of flow-dynamic pattern in a new sorbent cartridge for combined hemoperfusionhemodialysis; in Ronco C, Winchester JF (eds): Dialysis, Dialyzers and Sorbents. Contrib Nephrol. Basel, Karger, 2001, vol 133, pp 154165.

11 Ronco C, Brendolan A, Winchester JF, Golds E, Clemmer J, Polaschegg HD, Muller TE, Davankov V, Tsyurupa M, Pavlova L, Pavlov M, La Greca G, Levin NW: First clinical experience with an adjunctive hemoperfusion device designed specifically to remove beta-2microglobulin in hemodialysis; in Ronco $\mathrm{C}$, Winchester JF (eds): Dialysis, Dialyzers and Sorbents. Contrib Nephrol. Basel, Karger, 2001, vol 133, pp 166-173.
12 Reiter K, Bordoni V, Soffiati G, Fortunato L, Soli M, Galloni E, Winchester JF, Ronco C: In vitro removal of hormones by the Betasorb hemoperfusion cartridge, in press.

13 Raja RM: Resin hemoperfusion for drug intoxication - an update. Int J Artif Organs 1986;9: 319-322.

14 Stein G, Sperschneider H, Borner A, Stelzner A, Gunther K, Fünfstück R, Keil E, Lauterbach $\mathrm{H}$ : Influence of hemoperfusion with XAD-4 resin on the concentration of biologic constituents in the blood. Int J Artif Organs 1982;5: 105-109.

15 Lameire NH, De Vriese AS: Adsorption techniques and the use of sorbents; in Ronco C, Winchester JF (eds): Dialysis, Dialyzers and Sorbents. Contrib Nephrol. Basel, Karger, 2001, vol 133, pp 140-153.

16 Weber C, Rajnoch C, Loth F, Schima H, Falkenhagen D: The Microspheres based Detoxification System (MDS): A new extracorporeal blood purification technology based on recirculated microspherical adsorbent particles. Int J Artif Organs 1994;17:595-602. 